\title{
Formulation of Silkworm (Bombyx mori L.) Pupal Tamarind Ball and its Shelf Life Study
}

\author{
G.V. Vishaka ${ }^{1}$, D. Vijayalakshmi ${ }^{2}$, T.K. Narayanaswamy ${ }^{1 *}$ and R. Muthuraju ${ }^{3}$ \\ ${ }^{1}$ Department of Sericulture, ${ }^{2}$ Department of Food Science and Nutrition, ${ }^{3}$ Department of \\ Agricultural Microbiology, UAS, GKVK, Bengaluru-560065, Karnataka, India \\ *Corresponding author
}

\section{A B S T R A C T}

The results of the experiment carried out on the development of silkworm pupal tamarind ball (SPTB) with incorporation of silkworm pupal residue powder (SPRP) revealed that, 5

Keywords

Silkworm, Pupa,

Tamarind

Article Info

Accepted:

08 August 2018

Available Online:

10 September 2018 per cent SPRP incorporated SPTB was found to be best accepted with scores for appearance (7.5), colour (7.6), texture (7.8), aroma (7.8), taste (7.0) and overall acceptability (7.7). Silkworm pupal tamarind ball had better nutrient content as compared with the control tamarind ball. 5 per cent SPRP incorporated SPTB contained $4.6 \mathrm{~g}$ protein, $37.8 \mathrm{~g}$ carbohydrate, $0.6 \mathrm{~g}$ fat, $172 \mathrm{kcal}$ energy, $17.6 \mathrm{mg}$ calcium and $9.0 \mathrm{mg}$ iron. Microbial population of SPTB in initial day was found to be nil in case of all groups of microorganisms like bacterial, E. coli and molds. Bacteria of $5.37 \times 10^{4} \mathrm{CFU}$ and molds of $3.00 \times 10^{2} \mathrm{CFU}$ was noticed on $90^{\text {th }}$ day of storage. Interestingly, no $E$. coli was observed from initial to $90^{\text {th }}$ day of storage. The mean sensory evaluation scores of SPTB were recorded from initial day to end of storage study period for the best accepted SPTB (5\%). There was decrease in the overall acceptability from initial (7.7) to $90^{\text {th }}$ day of storage (6.0).

\section{Introduction}

Silk - The queen of textiles is the natural fiber, spells luxury, elegance, class and comfort, secreted by silkworm (Chandra, 1997). India is the second largest producer and also the largest consumer of silk in the world. In India, sericulture provide means of livelihood to a large section of population like mulberry, silkworm seed producer and cocoon producers $(56.8 \%)$, traders $(16.6 \%)$, weavers $(10.7 \%)$, twisters $(9.1 \%)$ and reelers $(6.8 \%)$ (www.Indiansilk.kar.nic.in).
Traditionally sericulture in India is practiced in tropical environmental regions such as Karnataka, Tamil nadu, Andhra Pradesh and West Bengal and to a limited extent in temperate regions of Jammu and Kashmir. In India mulberry is cultivated in 2, 16,810 hectares. The total raw silk production accounts for 30,348 MT of which mulberry silk is 21,273 MT and Vanya silk is 9,075 MT (Anonymous, 2017).

The silkworm (Bombyx mori L) is an economically important insect, which 
produces large quantity of silk. In silk reeling process, large quantity of waste accumulates in the form of pupae. Silkworm pupae contain numerous biological constituents which are of great value as feed for animals, human beings, medicine and manure for crops. The byproducts presently felt as wastes, can put to better use in generating the value based products and thereby catapult the industry to a more profitable and economically viable spot (Manohar Reddy, 2008).

Annually India produces about 40,000 MT of silkworm pupae on dry weight. Lots of desilked pupae have not been fully utilized. Indeed, disposed off desilked silkworm pupae is a serious problem because the putrilage of the waste are toxic. Recently, chemical composition of desilked pupae have attracted considerable attention in the world and desilked silkworm pupae are considered to be a good source of a large number of bioactive substances (Dandin and Rajan, 2005).

A silkworm pupae has long been part of human food in Asian silk producing countries and considered as delicacy. The vitamins like pyridoxal, riboflavin, thiamine, ascorbic acid, folic acid and minerals like calcium, iron and phosphorus make the pupae more nutritive (Koundinya and Thangavelu, 2005).

The pupa of silkworm has vast applications in a variety of field (Velayudhan et al., 2008). Effective use of by-products not only increases the rearer's and reeler's income but also helps in fuller utilization of natural resources. This vital aspect so far seems to have not been taken proper care in sericulture industry. The full utilization of silkworm pupae as different marketable products and such an integrated operation can certainly make the sericulture more practical.

The cost of end product i.e. the silk can be proportionately brought down by the combination of regulating the processing methods and converting the wastes as useful by-products. The optimal by-product utility concept can be highly useful to sericulture industry, which can help in elevating the socio economic status of the rural poor rearer's.

Profitable conversion of wastes/ by-products to high value utilities through phyto and postharvest technologies (Majumdar, 1997), the collaboration of seri scientists with related industries, to locate functional activities for potential applications can reduce the production cost, pollution, recycles resources to cater the ever growing population and their demanding wants.

At present the multipurpose use of silkworm pupae on a grand scale is yet to become a reality. The silkworm pupae serves as an alternative source to the soil, plants and humans to maintain their health with an idea of best from waste the experiment was planned and conducted in order to make fully utilization of silkworm pupae for preparation of silkworm pupal Tamarind Ball as part of value addition.

\section{Materials and Methods}

The investigation on the development of SPTB with incorporation of SPRP was conducted at Department of Food Science and Nutrition, University of Agricultural Sciences, Gandhi Krishi Vighyan Kendra, Bengaluru.The materials used and the methods adopted during the study are detailed below.

\section{Preparation of tamarind ball}

\section{Ingredients required}

Tamarind, garlic, coriander powder, cumin powder, salt, sugar, chilli powder and silkworm pupal residue powder (concentration 2.5, 5 and $7 \%$ ). 


\section{Procedure}

Tamarind, garlic, coriander powder, cumin powder, salt, sugar, chili powder were mixed well in a grinder and made in to bite size balls later balls were rolled on sugar to coat evenly.

Nutrient and biochemical composition was estimated by adopting the standard procedures for protein, fat, calcium, Iron, energy and CHO by using AOAC (1980) method.

\section{Organoleptic evaluation}

The Value added product was standardized in laboratory and organoleptic evaluation was carried out. A nine point Hedonic Scale was adopted for the evaluation by 21 semi trained panelists.

\section{Estimation of anti-nutritional factors}

The anti-nutritional factors such as phytic acid and tannins were estimated.

\section{Microbial load of silkworm pupal residue powder and product developed out of it}

Ten grams of SPRP and products sample was mixed in $90 \mathrm{ml}$ sterile water blank to give $10^{-1}$ dilution. Subsequent dilutions up to $10^{-4}$ were made by transferring serially $1 \mathrm{ml}$ of the dilution to $9 \mathrm{ml}$ of sterile water blanks. The populations of bacteria, molds and yeasts were estimated by transferring $1 \mathrm{ml}$ of $10^{-2}, 10^{-3}$ and $10^{-4}$ dilutions respectively to a sterile Petridish and approximately $20 \mathrm{ml}$ of media viz., Nutrient Agar, Martins Rose Bengal Agar and Davis Yeast Extract Agar for bacteria, molds and E. coli respectively was poured into plates. The plates were rotated twice in clockwise and anticlockwise direction for uniform distribution of the inoculums. After solidifications of the media, plates were kept for incubation in an invert position at $30 \pm 11^{\circ} \mathrm{C}$ for2-4 days and emerged colonies were counted. The cost of the product was calculated per $100 \mathrm{~g}$ of the product. The cost of the product was calculated by taking into consideration the cost of ingredients and overhead charges. Though the overhead charges are same for all the products the cost of production varied according to the cost of ingredients.

\section{Statistical analysis}

The data of the experiment was subjected to appropriate statistical analysis. One way analysis of variance was applied to sensory scores. The analysis of variance and interpretation of data were done as per procedures given by Fisher and Yates (1963) and Panse and Sukhatme (1985). Level of significance used in ' $\mathrm{F}$ ' test was $\mathrm{P}=0.05$.

\section{Results and Discussion}

Results on sensory evaluation of SPTB revealed that, three variations of SPTB were prepared by incorporating SPRP at different levels (2.5, 5 and 7 per cent). Control tamarind balls were prepared without the addition of SPRP. Control tamarind balls scored higher values for sensory attributes for appearance, colour, texture, aroma, taste and overall acceptability of 8.1, 7.8, 8.1, 8.0, 8.4 and 8.0 respectively. Among different levels of SPRP incorporation, 5 per cent found to be best accepted with scores for appearance (7.5), colour (7.6), texture (7.8), aroma (7.8), taste (7.0) and overall acceptability (7.7). However, least scores were observed for SPTB prepared by incorporating 7 per cent of SPRP with scores for appearance (7.3), colour (7.5), texture (7.6), aroma (6.5), taste (6.2) and overall acceptability (7.0) respectively (Table $1)$.

The sensory scores of SPTB was found to be best for 5 per cent SPRP incorporated tamarind ball for all the sensory attributes 
viz., appearance, colour, texture, aroma, taste and overall acceptability. The silkworm pupal residue powder along with garlic, cumin powder and coriander powder might also have added the better taste for the tamarind ball. This was in accordance with Padmashree et al., (2012) reported similar values for cereal chocolate nutria bars.

Nutrient compositions per $100 \mathrm{~g}$ of control (0 $\%$ SPRP incorporation) tamarind ball i.e. protein, carbohydrate, fat and energy was 1.8 $\mathrm{g}, 36.6 \mathrm{~g}, 0.1 \mathrm{~g}$ and $153 \mathrm{k}$ cal respectively. The calcium and iron were 12.4 and $8.6 \mathrm{mg}$. SPTB at 5 per cent SPRP incorporated level contained $4.6 \mathrm{~g}$ protein, $37.8 \mathrm{~g}$ carbohydrate, $0.6 \mathrm{~g}$ fat, $172 \mathrm{kcal}$ energy, $17.6 \mathrm{mg}$ calcium and $9.0 \mathrm{mg}$ iron (Table 2).

SPTB had better nutrient content as compared with the control tamarind ball as the formulation included silkworm pupal powder. The nutritional and biochemical analysis revealed by Tomotake et al., (2010) showed that, silkworm pupal powder is very rich in the nutritional and biochemical compositions. So, this has added the extra nutrient status compared to that of the control.

\section{Microbial load of SPTB on storage}

Microbial population of control tamarind ball at initial day was found to be nil in case of all groups of microorganisms like bacterial, $E$. coli and molds. But at $10^{\text {th }}, 30^{\text {th }}, 60^{\text {th }}$ and $90^{\text {th }}$ day the total bacterial count was $1.3 \times 10^{4} \mathrm{CFU}$, $1.7 \times 10^{4} \mathrm{CFU}, 2.8 \times 10^{4} \mathrm{CFU}$ and $5.7 \times 10^{4} \mathrm{CFU}$ respectively. However, from initial to $90^{\text {th }}$ day no $E$. coli population was observed. Whereas, there were no mold population from initial to $60^{\text {th }}$ day, but on $90^{\text {th }}$ day there was $1 \times 10^{2} \mathrm{CFU}$ molds were recorded (Table 3 ).

Microbial population of SPTB at initial day was found to be nil in case of all groups of microorganisms like bacterial, E. coli and molds. But at $10^{\text {th }}, 30^{\text {th }}, 60^{\text {th }}$ and $90^{\text {th }}$ day the total bacterial count was $1.41 \times 10^{4} \mathrm{CFU}$, $1.87 \times 10^{4} \mathrm{CFU}, 2.73 \times 10^{4} \mathrm{CFU}$ and $5.37 \times 10^{4}$ $\mathrm{CFU}$ respectively. However, there was no presence of $E$. coli from initial day to $90^{\text {th }}$ day. Whereas, from initial day to $60^{\text {th }}$ day there were no molds noticed. Later, the molds were found to be $3 \times 10^{2}$ CFU on $90^{\text {th }}$ day respectively. There was a significant difference between total bacterial population counts from initial day to $90^{\text {th }}$ day (Table 3 ).

In the storage conditions, the microbial load has been increased as the days of storage increased. As the silkworm tamarind ball contained the formulations of garlic might have showed the immune power against different microbes. Hence, there were no $\mathrm{E}$. coli populations and molds noticed till $60^{\text {th }}$ day of storage. The results are on par with work of Selvaraj et al., (2002) reported that masala biscuits had increased the microbial load with increase in the storage days.

\section{Shelf life study of SPTB}

The control and silkworm pupal tamarind balls (5 per cent level SPRP incorporated tamarind balls) which were best accepted by the sensory panel members kept for shelf life study. The samples were observed daily for visual changes and were subjected to sensory evaluation on $30^{\text {th }}, 60^{\text {th }}$ and $90^{\text {th }}$ days respectively. The results of the mean sensory score evaluation of control tamarind ball from initial day to end of shelf life study period are presented. The control tamarind ball showed sensory scores of 7.4, 7.3, 7.3, 7.4, 7.5 and 7.4 for all the sensory attributes viz., appearance, colour, texture, aroma, taste and overall acceptability for the initial day. However, at the end of $90^{\text {th }}$ day, the control tamarind ball had low sensory scores $(7.2,6.7,6.3,6.6,6.9$ and 7.1) for appearance, colour, texture, aroma, taste and overall acceptability (Table 4). 
Table.1 Mean sensory scores of silkworm pupal tamarind ball

\begin{tabular}{|c|c|c|c|c|c|c|}
\hline \multirow{3}{*}{$\begin{array}{l}\text { Level of } \\
\text { silkworm pupal } \\
\text { residue powder } \\
\text { incorporation } \\
(\%)\end{array}$} & \multicolumn{6}{|c|}{ Mean sensory scores $(n=21)$} \\
\hline & \multicolumn{6}{|c|}{ Sensory attributes } \\
\hline & Appearance & Colour & Texture & Aroma & Taste & $\begin{array}{l}\text { Overall } \\
\text { acceptability }\end{array}$ \\
\hline Control & 8.1 & 7.8 & 8.1 & 8.0 & 8.4 & 8.0 \\
\hline 2.5 & 7.3 & 7.5 & 7.8 & 7.2 & 6.7 & 7.5 \\
\hline 5 & 7.5 & 7.6 & 7.8 & 7.8 & 7.0 & 7.7 \\
\hline 7 & 7.3 & 7.5 & 7.6 & 6.5 & 6.2 & 7.0 \\
\hline Mean & 7.5 & 7.6 & 7.8 & 7.3 & 7.0 & 7.5 \\
\hline F- Test & $*$ & $*$ & $*$ & $*$ & $*$ & $*$ \\
\hline S. Em \pm & 0.17 & 0.29 & 0.13 & 0.13 & 0.19 & 0.25 \\
\hline CD at $5 \%$ & 0.4 & 0.8 & 0.38 & 0.37 & 0.56 & 0.7 \\
\hline
\end{tabular}

*-Significant at $5 \%$

Table.2 Nutritional composition of silkworm pupal tamarind ball per $100 \mathrm{~g}$

\begin{tabular}{|c|c|c|}
\hline Nutrients & $\begin{array}{c}\text { Control } \\
(\mathbf{0} \% \text { SPRP) }\end{array}$ & $\begin{array}{c}\text { Best accepted product } \\
(\mathbf{5} \% \text { SPRP incorporated })\end{array}$ \\
\hline Protein(g) & 1.8 & 4.6 \\
\hline Carbohydrates (g) & 36.6 & 37.8 \\
\hline Fat (g) & 0.1 & 0.6 \\
\hline Energy (Kcal) & 153 & 172 \\
\hline Calcium (mg) & 12.4 & 17.6 \\
\hline Iron(mg) & 8.6 & 9.0 \\
\hline
\end{tabular}

SPRP- Silkworm pupal residue powder 
Table.3 Microbial load of best accepted silkworm pupal tamarind ball on storage (5\% SPRP incorporated)

\begin{tabular}{|c|c|c|c|c|}
\hline \multirow{2}{*}{ Samples } & \multirow{2}{*}{$\begin{array}{c}\text { Duration } \\
\text { (Days) }\end{array}$} & \multicolumn{3}{|c|}{ Group of microorganisms } \\
\hline & & $\begin{array}{l}\text { Total Bacterial } \\
\text { count }\left(\times 10^{4} \text { CFU }\right)\end{array}$ & $\begin{array}{c}\text { E. coli } \\
\left(\times 10^{2} \text { CFU }\right)\end{array}$ & $\begin{array}{c}\text { Molds } \\
\left(\times 10^{2} \text { CFU } / g\right)\end{array}$ \\
\hline \multirow{10}{*}{ Control } & Initial & Nil & Nil & Nil \\
\hline & $10^{\text {th }}$ day & 1.3 & Nil & Nil \\
\hline & $30^{\text {th }}$ day & 1.7 & Nil & Nil \\
\hline & $60^{\text {th }}$ day & 2.8 & Nil & Nil \\
\hline & $90^{\text {th }}$ day & 5.7 & Nil & 1 \\
\hline & Mean & 2.8 & - & - \\
\hline & F-test & $*$ & - & - \\
\hline & S. Em \pm & 0.10 & - & - \\
\hline & CD at $5 \%$ & 0.35 & - & - \\
\hline & Initial & Nil & Nil & Nil \\
\hline \multirow[t]{8}{*}{$5 \%$ SPRP incorporated } & $10^{\text {th }}$ day & 1.41 & Nil & Nil \\
\hline & $30^{\text {th }}$ day & 1.87 & Nil & Nil \\
\hline & $60^{\text {th }}$ day & 2.73 & Nil & Nil \\
\hline & $90^{\text {th }}$ day & 5.37 & Nil & 3 \\
\hline & Mean & 2.28 & - & - \\
\hline & F-test & $*$ & - & - \\
\hline & S. Em \pm & 0.33 & - & - \\
\hline & CD at $5 \%$ & 1.05 & - & - \\
\hline
\end{tabular}

\section{*-Significant at $5 \%$}

Table.4 Mean sensory scores for shelf life study of best accepted silkworm pupal tamarind ball (5\% SPRP incorporated)

\begin{tabular}{|c|c|c|c|c|c|c|c|}
\hline \multirow[b]{3}{*}{ Products } & \multirow{3}{*}{$\begin{array}{c}\text { Duration } \\
\text { (Days) }\end{array}$} & \multicolumn{6}{|c|}{ Mean sensory scores $(\mathrm{n}=\mathbf{2 1})$} \\
\hline & & \multicolumn{6}{|c|}{ Sensory attributes } \\
\hline & & Appearance & Color & Texture & Aroma & Taste & Overall acceptability \\
\hline & Initial & 7.4 & 7.3 & 7.3 & 7.4 & 7.5 & 7.4 \\
\hline \multirow{8}{*}{ Control } & $30^{\text {th }}$ & 7.3 & 7.0 & 7.1 & 7.2 & 7.5 & 7.1 \\
\hline & $60^{\text {th }}$ & 7.3 & 6.7 & 7.0 & 6.9 & 7.4 & 7.1 \\
\hline & $90^{\text {th }}$ & 7.2 & 6.7 & 6.3 & 6.6 & 6.9 & 7.1 \\
\hline & Mean & 6.5 & 6.9 & 6.4 & 6.7 & 6.6 & 6.8 \\
\hline & F-test & NS & $*$ & $*$ & $*$ & NS & NS \\
\hline & S. Em \pm & 0.18 & 0.13 & 0.16 & 0.14 & 0.19 & 0.13 \\
\hline & CD at $5 \%$ & 0.48 & 0.35 & 0.45 & 0.40 & 0.53 & 0.36 \\
\hline & Initial & 7.9 & 7.8 & 7.9 & 7.7 & 7.7 & 7.7 \\
\hline \multirow{7}{*}{$\begin{array}{l}5 \% \text { SPRP } \\
\text { incorporated } \\
\end{array}$} & $30^{\text {th }}$ & 7.7 & 7.3 & 7.6 & 7.5 & 7.4 & 7.3 \\
\hline & $60^{\text {th }}$ & 7.3 & 7.0 & 7.2 & 7.1 & 6.9 & 6.8 \\
\hline & $90^{\text {th }}$ & 6.9 & 6.6 & 6.8 & 6.6 & 6.4 & 6.0 \\
\hline & Mean & 7.4 & 7.1 & 7.3 & 7.2 & 7.1 & 6.9 \\
\hline & F-test & $*$ & $*$ & $*$ & $*$ & $*$ & NS \\
\hline & S. Em \pm & 0.23 & 0.19 & 0.2 & 0.27 & 0.21 & 0.17 \\
\hline & CD at $5 \%$ & 0.67 & 0.54 & 0.56 & 0.78 & 0.6 & 0.48 \\
\hline
\end{tabular}

*- Significant at $5 \%$; NS- Non-significant 
Table.5 Microbial load of silkworm pupal powder on storage

\begin{tabular}{|c|c|c|c|c|}
\hline \multirow{2}{*}{ Samples } & $\begin{array}{c}\text { Duration } \\
\text { (Days) }\end{array}$ & $\begin{array}{c}\text { Total Bacterial } \\
\text { count }\left(\times \mathbf{1 0}^{\mathbf{4}} \mathbf{C F U}\right)\end{array}$ & $\begin{array}{c}\text { E.coli } \\
\left(\times \mathbf{1 0}^{\mathbf{2}} \mathbf{C F U}\right)\end{array}$ & $\begin{array}{c}\text { Molds } \\
\left(\times \mathbf{1 0}^{\mathbf{2}} \mathbf{C F U} / \mathbf{g}\right)\end{array}$ \\
\hline & Initial & Nil & Nil & Nil \\
\hline $10^{\text {th }}$ day & 1.28 & Nil & Nil \\
\hline $30^{\text {th }}$ day & 2.23 & Nil & Nil \\
\hline $60^{\text {th }}$ day & 3.63 & Nil & Nil \\
\hline $90^{\text {th }}$ day & 4.03 & Nil & 3 \\
\hline Mean & $\mathbf{2 . 2 4}$ & - & - \\
\hline F-test & $*$ & - & - \\
\hline S. Em \pm & $\mathbf{0 . 4 8}$ & - & - \\
\hline CD at 5 \% & $\mathbf{1 . 5 2}$ & - & - \\
\hline
\end{tabular}

*-Significant at $5 \%$

Table.6 Production cost of best accepted silkworm pupal tamarind ball (5\% SPRP incorporated) (Round off to Rs.10)

\begin{tabular}{|l|}
\hline Ingredients \\
\hline Tamarind \\
\hline Garlic \\
\hline Cumin powder \\
\hline Coriander powder \\
\hline Sugar \\
\hline Chilli \\
\hline Salt \\
\hline Pupal powder \\
\hline Total \\
\hline Overhead charges $(20 \%$ of the cost) \\
\hline Cost of the product $/ 100 \mathrm{~g}$ \\
\hline
\end{tabular}

\begin{tabular}{|c|c|c|}
\hline Price $/ \mathrm{kg}(\mathbf{R s})$ & Quantity $(\mathrm{g})$ & Price $(\mathrm{Rs})$ \\
\hline 80 & 50 & 4 \\
\hline 150 & 3 & 0.45 \\
\hline 210 & 0.5 & 0.11 \\
170 & 0.5 & 0.09 \\
\hline 45 & 2 & 0.09 \\
60 & 2 & 0.12 \\
\hline 20 & 1 & 0.02 \\
\hline $\mathbf{2 0}$ & $\mathbf{2 . 5}$ & $\mathbf{0 . 0 5}$ \\
\hline & 61.5 & 4.93 \\
& & 0.99 \\
& 61.5 & 5.92 \\
\hline & 100 & 9.63 \\
\hline
\end{tabular}

Overhead charges- Cooking, processing and utilities

Rs.10 per 100gm of the product both for control and silkworm pupal tamarind ball

The 5 per cent level incorporated SPTB showed scores of 7.9, 7.8, 7.9, 7.7, 7.7 and 7.7 for all sensory parameters viz., appearance, colour, texture, aroma, taste and overall acceptability for the initial day. However, at the end of 90th day the 5 per cent level of incorporation of SPTB showed lower scores (6.9, 6.6, 6.8, 6.6, 6.4 and 6.o) for appearance, colour, texture, aroma, taste and overall acceptability. By the $100^{\text {th }}$ day they were unfit for sensory evaluation due to increase in the peroxide and free fatty acid value. When analyzed statistically there was significant difference among appearance, colour, texture, aroma and taste except for overall acceptability from initial to $90^{\text {th }}$ day (Table 4).

The sensory evaluation of SPTB at storage conditions showed that, there was decrease in the scores for all the sensory attributes at $90^{\text {th }}$ day of storage. Due to increase of microbial load in the SPTB also adds up for the 
decrease in the sensory attributes. These findings are in relation with the findings of Bhardwaj et al., (2016) who prepared guava milk chocolate and a shelf life study for same was reported.

\section{Microbial load of SPRP on storage}

Microbial population of SPRP in initial day was found to be nil in case of all groups of microorganisms like bacterial, E. coli and molds. But at $10^{\text {th }}, 30^{\text {th }}, 60^{\text {th }}$ and $90^{\text {th }}$ day $1.28 \times 10^{4}$ CFU, $2.23 \times 10^{4}$ CFU, $3.63 \times 10^{4}$ CFU and $4.03 \times 10^{4} \mathrm{CFU}$ of total bacteria was recorded respectively. However, there was no presence of $E$. coli from initial day to $90^{\text {th }}$ day. Whereas, from initial day to $60^{\text {th }}$ day there were no molds noticed. Later, the molds were found to be $3 \times 10^{2} \mathrm{CFU}$ at $90^{\text {th }}$ day respectively. There was a significant difference between total bacterial population counts from initial day to $90^{\text {th }}$ day (Table 5).

As the silkworm pupal powder is rich in biochemical compositions and nutrient compositions (Mishra et al., 2003) and also the ability of silkworm pupal powder to absorb moisture have attracted the microbes. This is the first kind of study and literature pertaining to it is not available and hence it was not compared.

\section{Anti-nutritional content of SPRP}

The SPRP contained $140 \mathrm{mg}$ of phytic acid and $0.2 \mathrm{mg}$ of tannin/ $100 \mathrm{~g}$ of powder. The results of anti-nutritional content of SPRP was compared with phytic acid and tannin content of finger millet which was in the range of $225-347 \mathrm{mg} / 100 \mathrm{gm}$ and $0.28-1.20$ $\mathrm{mg} / 100 \mathrm{gm}$ (Hiremath, 2011).

The production cost of control and silkworm pupal tamarind balls was Rs. 10 /100g (Table 5). The production cost was estimated by taking the prevailing cost of all the ingredients in the market and the overhead cost including the labour cost, power cost, machinery cost and packaging cost. Though the same overhead charges were taken for all the products the cost of product varied, because of varied cost of ingredients. The estimated costs were within the reach of Indian costumers.

Three variations of SPRP of 2.5, 5 and 7 per cent were incorporated for preparation of SPTB. However, 5 per cent incorporated SPTB was best accepted. The present study can be extended to study the consumer acceptability and popularization of SPTB prepared using silkworm pupal residue powder.

\section{Acknowledgement}

The authors greatly acknowledge the financial assistance provided through DBT funded project entitled" Characterization of silkworm pupal bioprotein and processing for value addition" from DBT, New Delhi and Department of Sericulture, UAS,GKVK, Bengaluru for providing facilities to conduct research.

\section{References}

A.O.A.C. 1980. Official methods of analysis, 13th edition, Association of Official Analytical Chemists, Washington, DC.

Anonymous, 2017. Raw silk production in India. CSB Ann. Rep., pp.1-118.

Bhardwaj, R, Mishra, D., Chaun, A.K., Kumar, P. and Yadav, D., 2016, Optimization of guava milk chocolate using response surface methodology. Biosci. Biotechnol. Res. Asia., 13(3): 1715-1723.

Chandra, H., 1997, Studies on aero-phyllo microflora of oak ( $Q$ serrata Thumb) in Manipur with special reference to certain bacterial diseases of Oak Tasar 
Silkworm (A. proylei Jolly). In Ph.D. Thesis: pp. 1-2.

Dandin, S.B. and Rajan, M.V., 2005, Utilization of byproduct of sericulture A felt need. In: Advances in organic sericulture and seri byproducts utilization, pp. 93-99.

Fisher, R. A. and Yates, F. 1963, Statistical Tables for Biological, Agricultural and Medical Research, Sixth edition, Oliver and Boyd, Edinburgh.

Hiremath, P. S., 2011, Physico-chemical charecteristics of raw, malted and popped finger millet varieties. M.sc. thesis. Univ. Agric. Sci. Darwad, Bangalore, pp. 56-74.

Koundinya, P. R. and Thangavelu, K., 2005, Silk proteins in biomedical research. Indian Silk, 43(11): 5-8.

Majumder, S. K., 1997, Scope for new commercial products from sericulture. Indian Silk, 35 (12): 13-18.

Manohar Reddy, R., 2008, Value addition Span of Silkworm cocoon - Time for utility optimization. Int. J. Indust. Entomol, 17 (1): 109-113.

Mishra, N., Hazarika, N. C., Narain, K. And Mahantaj, 2003, Nutritive value of non- mulberry and mulberry silkworm pupae and consumption pattern in Assam, India J. Nutrition research, 23: 1303-1311.

Padmashree, A., Sharma, G. K., Srihari, K. A. and Bawa, A.S., 2012, Development of shelf stable protein rich composite ceral bar. J. Food Sci. Technol., 49 (3): 335341.

Panse, V. G. and Sukhatme, P. V., 1985, Statistical Methods for Agricultural Workers. 2nd edn. ICAR. New Delhi.

Selvaraj, A., Balasubramanyam, N. and Rao, P. H., 2002, Packaging and storage studies on biscuits containing finger millet (ragi) flour. J. Fd. Sci. Technol., 39(1): 66-68.

Tomotake, H., Katagiri, M., and Yamato, M., 2010, Silkworm pupae (Bombyx mori) are new sources of high quality protein and lipid. J. Nutr. Sci Vitaminol., 56: 446-448.

Velayudhan, K., Balachandran, N. Sinha, R.K. and Kamble, C. K., 2008, Utility of silkworm pupae: A new dimension as food and medicine. Indian Silk, 47 (1): 11-18.

\section{How to cite this article:}

Vishaka, G.V., D. Vijayalakshmi, T.K. Narayanaswamy and Muthuraju, R. 2018. Formulation of Silkworm (Bombyx mori L.) Pupal Tamarind Ball and Its Shelf Life Study. Int.J.Curr.Microbiol.App.Sci. 7(09): 885-893. doi: https://doi.org/10.20546/ijcmas.2018.709.106 